Care: Jurnal Ilmiah Ilmu Kesehatan Vol .7, No.3, 2019, hal 84-96

Tersedia online di https://jurnal.unitri.ac.id/index.php/care

ISSN 2527-8487 (online)

ISSN 2089-4503 (cetak)

\title{
EFEKTIFITAS PELATIHAN PERAWATAN LUKA TINGKAT DASAR DI BAPELKES BATAM DALAM MENINGKATKAN KEMAMPUANTENAGA KEPERAWATAN DI PROVINSI KEPULAUAN RIAU
}

\author{
Wilda Hayati ${ }^{1}$, Endan Suwandana ${ }^{2)}$ \\ ${ }^{1)}$ Balai Pelatihan Kesehatan Batam, \\ ${ }^{2)}$ Badan Pengembangan Sumber Daya Manusia Provinsi Banten \\ E-mail: wildanovri@yahoo.co.id, endan2006@yahoo.com
}

\begin{abstract}
The improvement of wound care capabilityof nurses needs to be continually conducted due to the development in science and technology of the wound care. One way to improve the capabilityof the nurse can be achievedby conducting a training program. This paper is aimed to assess the effectiveness of the basic level wound care training program at Health Training Center (Bapelkes) of Batam in the improvement of the nurses' capabilities in the Kepulauan Riau Province. Thisstudy implements qualitative descriptive method by using questionnaires as research instrument which were distributed to three groups of respondents, i.e. the alumni, the alumni's mentors, and the alumni's working partners, out of three training batches between 2011-2013. The variables evaluated in this study include performance, working motivation, professional competency, and training competency. Descriptive statistical analysis methods and analytic statistics (simple linear regression) are also used in data analysis. The results of the study show that the training program is effective in improving the nurses' capability in all evaluated variables with the average improvement percentage of 96,88\% (based on response of the alumni), 90,63\% (based on the response of the alumni's mentors), and 92,19\% (based on the response of the alumni's working partners). The study also concludes that the correlation of responsesamong the group of respondents showing that the correlation of the responses between the alumni and the alumni's mentors is strongly significant with the coefficient correlation $\left(R^{2}\right)$ of 0.804 and strong with the $R^{2}$ of 0,516 for the correlation of the responses between the alumni and the alumni's working partners. This means that the assessment given by training alumni, alumni superiors and alumni colleagues is not biased and the three groups of respondents suppot each other/ have in common, assessments given by training alumni and above alumni have a very strong relationship with the correlation coefficient (R2) 0.804 .
\end{abstract}

Keywords : Post-training evaluation; wound care; nurse.

\begin{abstract}
ABSTRAK
Peningkatan kemampuan perawatan luka perlu terus dilakukan terhadap tenaga keperawatan mengingat ilmu pengetahuan dan teknologi tentang perawatan luka terus mengalami perkembangan.Salah satu upaya untuk meningkatkan kemampuan tenaga keparawatan tersebut adalah melalui kegiatan pelatihan. Tulisan ini bertujuan untuk mengkaji efektifitas pelatihan perawatan luka tingkat dasar dalam meningkatkan kemampuan tenaga keperawatan se-Kepulauan Riau yang dilaksanakan di Balai Pelatihan Kesehatan (Bapelkes) Batam. Penelitian ini menggunakan metode dekriptif kualitatif dengan teknik kuesioner yang diujikan kepada tiga kelompok responden, yaitu alumni, atasan alumni, dan rekan kerja alumni dari tiga angkatan pelatihan yang dilaksanakan pada tahun 2011 - 2013. Variabel yang diujikan mencakup unsur kinerja, motivasi kerja, kompetensi profesionalisme, dan kompetensi pelatihan.Metode analisis statistik deskriptif dan statistik analitik (regresi linier sederhana) juga digunakan dalam analisa data. Kajian ini menunjukkan bahwa pelatihan ini cukup efektif untuk meningkatkan kemampuan alumni pada seluruh variable yang diujikan dengan

Cara mengutip: Hayat, Wilda, \& Suwandana, Endan. (2019). Efektifitas Pelatihan Perawatan Luka Tingkat Dasar Di Bapelkes Batam Dalam Meningkatkan Kemampuantenaga Keperawatan Di Provinsi Kepulauan Riau . Care:Jurnal Ilmiah Ilmu Kesehatan, 7(3), 84-96


rata-rata persentase peningkatan sebesar 96,88\% (menurut alumni), 90,63\% (menurut atasan), dan 92,19\% (menurut rekan kerja). Dilihat dari sisi kesesuaian jawaban yang diberikan oleh antar kelompok responden, kajian ini menunjukkan korelasi yang sangat signifikan dengan koefisien korelasi $\left(R^{2}\right)=$ 0,804 untuk korelasi antara jawaban alumni dan atasan alumni serta signifikan dengan $R^{2}=0,516$ untuk korelasi antara jawaban alumni dan rekan kerja alumni.Artinya penilaian yang diberikan oleh alumni pelatihan, atasan alumni dan rekan kerja alumni tidak bias dan ketiga kelompok responden saling mendukung/ memiliki kesamaan, penilaian yang diberikan oleh alumni pelatihan dan atasn alumni memiliki hubungan yang sangat kuat dengan koefisien korelasi $\left(R^{2}\right) 0,804$.

Kata Kunci : Evaluasi pasca pelatihan; perawatan luka; perawat.

\section{PENDAHULUAN}

Perkembangan ilmu pengetahuan mengenai perawatan luka sangat pesat pada tahun-tahun terakhir (Rostini, et al., 2013).Lebih-lebih hal tersebut ditunjang oleh kemajuan teknologi dalam bidang kesehatan (Nontji, et al, 2015).Apalagi dewasa ini profil pasien pun mengalami perubahan, dimana saat ini semakin banyak dijumpai pasien dengan kondisi penyakit degeneratif (Dahro, et al., 2012) dan kelainan metabolik (Prahastuti, 2011). Di sisi lain para tenaga medis pun dituntut untuk melakukan efisiensi (cost effectiveness) dalam melakukan penanganan luka (Handayani, 2016). Beberapa hal tersebut tentunya akan meningkatkan kompleksitas penanganan suatu luka oleh tenaga medis.

Maka diperlukan upaya untuk meningkatkan kemampuan / kompetensi tenaga medis mengenai teknik perawatan luka. Upaya peningkatan kompetensi itu menurut Peraturan Pemerintah (PP) No. 11 Tahun 2017 tentang Manajemen Pegawai Negeri Sipil dapat dilakukan melalui berbagai cara di antaranya adalah melalui pendidikan dan pelatihan, workshop, seminar, kursus, penataran, dan pemagangan. Tujuan kajian ini adalah untuk mengukur efektifitas pelaksanaan pelatihan dalam meningkatkan kemampuan tenaga medis dalam perawatan luka.

Pelatihan merupakan salah satucara terstruktur (Robbins, 1996) untuk meningkatkan kemampuan sumber daya manusia (SDM) dalam rangka memperbaiki performa pekerja pada suatu pekerjaan tertentu yang sedang menjadi tanggung jawabnya (Gomes, 2005) yang dikemas dalam bentuk pembelajaran yang menggabungkan antara pengalaman, pengetahuan, keterampilan dan sikap (Atmodiworo, 2000; Bernardin and Russel, 1993) dan diakhiri dengan kegiatan evaluasi pasca pelatihan untuk mengetahui efektivitas program pelatihan yang telah dilaksanakan (Busyra, 2011).

Efektifitas pelaksanaan sebuah pelatihan itu sendiri dapat diukur dari tiga hal yaitu input, conversion, dan output (Jones 1994). Sejalan dengan itu, Gomes (2005) melengkapi bahwa efektifitas sebuah program dapat dievaluasi berdasarkan reactions,learning process, behaviors, danorganizational results. Efektifitas sebuah 
program dapat dinilai dari keberhasilan individu, kelompok dan organisasi (Gibson, et al., 1997). Dari sisi kemampuan peserta, unsur yang dapat dinilai adalah 1) peningkatan kemampuan dalam melaksanakan tugas, dan b) perubahan perilaku yang tercermin dalam sikap, disiplin dan etos kerja (Notoatmodjojo, 2009).

Materi pelatihan Perawatan Luka Tingkat Dasar yang dikembangkan di Balai Pelatihan Kesehatan (Bapelkes) Batam menggunakan pendekatan konsep, teori dan teknik dalam pelaksanaan manajemen perawatan luka yang efektif dengan materi-materi pelatihan yang meliputi:

1. Melakukan wound bed preparation

2. Melakukan pengkajian luka

3. Melakukan universal precaution pada perawatan luka

4. Melakukan pemilihan topical therapy

5. Melakukan manajemen fistula dan parcel dressing

6. Melakukan lenatalaksanaan luka (akut, kronik dan drain)

7. Menjelaskan nutrition support in wound care

8. Melakukan pain management in wound care.

Tujan dari penelitian ini adalah untuk menguji efektifitas dari kegiatan pelatihan perawatan luka tingkat dasar dalam meningkatkan kemampuan tenaga keperawatan serta untuk menguji apakah ada hubungan antara penilaian yang diberikan oleh para alumni itu sendiri dengan penilaian yang diberikan oleh atasan alumni dan rekan kerja alumni tentang peningkatan kemampuan alumni dalam melakukan perawatan luka.

\section{METODE PENELITIAN}

Kajian ini menggunakan pendekatan metode deskriptif kualitatif dengan bantuan kuesioner sebagai instrumen penelitian. Kegiatan ini didasarkan pada data primer sebagai hasil dari kegiatan evaluasi pasca pelatihan dari Pelatihan Perawatan Luka Tingkat Dasar yang dilaksanakan di Balai Pelatihan Kesehatan (Bapelkes) Batam dari tahun 2011-2013 sebanyak tiga angkatan. Responden dalam penelitian ini terbagi dalam tiga kelompok yaitu 1) alumni pelatihan, 2) atasan alumni, dan 3) rekan kerja alumni, dengan jumlah total responden 175 orang yang terdiri dari beberapa instansi, Kantor Kesehatan Pelabuhan (KKP), Rumah Sakit (RS), Puskesmas, Klinik Poltabes/ Kodim/ Rumah Tahanan.

Ada tiga aspek (variable) yang dievaluasi dari para alumni pelatihan yaitu aspek kognitif, afektif dan psikomotorik.Menurut Bloom (1956), aspek kognitif adalah aspek kemampuan peserta dalam menyerap informasi, konsep, teori dan pengetahuan lainnya. Aspek afektif adalah ranah yang berkaitan dengan watak, perilaku, perasaan, minat, sikap, emosi, dan nilai.Aspek psikomotor merupakan aspek yang berkaitan dengan keterampilan (skill) atau kemampuan bertindak.Selain ketiga hal tersebut dievaluasi 
juga mengenai bagaimana manfaat pelatihan terhadap individu dan organisasi alumni.

Aspek kognitif yang dinilai dari para alumni pelatihan meliputi:

1. Pengetahuan/hafalan/ingatan (knowledge)

2. Pemahaman (comprehension)

3. Penerapan (application)

4. Analisis (analysis)

5. Sintesis (syntesis)

6. Penilaian/penghargaan/evaluasi (evaluation)

Aspek afektif yang dinilai dari para alumni pelatihan meliputi:

1. Receiving atau attending (menerima atau memperhatikan)

2. Responding (menanggapi) mengandung arti "adanya partisipasi aktif"

3. Valuing (menilai / menghargai)

4. Organization(mengatur/mengorganisasi)

5. Characterization by evalue or calue complex (karakterisasi dengan suatu nilai atau komplek nilai).

Aspek psikomotorik yang dinilai dari para alumni pelatihan meliputi:

1. Pengkajian luka

2. Pencegahan infeksi (universal precaution)

3. Pemilihan jenis tindakan (topical therapy)

4. Manajemen fistula dan parcel dressing

5. Pemilihan nutrisi pada proses penyembuhan luka

6. Pengelolaan rasa sakit (pain management)

Ketiga aspek tersebut kemudian dikembangkan menjadi kuesioner yang didesain dan dibagikan kepada masing-masing kelompok responden:alumni, atasan alumni, danteman kerja alumni. Kuesioner yang dibagikan kepada para alumni terdiri dari lima bagian, yaitu:

1. Identitas responden ( 9 pertanyaan)

2. Penilaian terhadap mutu penyelenggaraan pelatihan (11 pertanyaan)

3. Penilaian terhadap peningkatan kinerja yang terdiri dari unsur dimensi kinerja (6 pertanyaan), motivasi kerja (4 pertanyaan), kompetensi professional (8 pertanyaan), dan kompetensi pelatihan (33 pertanyaan)

4. Penilaian terhadap faktor pendukung dan penghambat dalam penerapan hasil pelatihan ( 2 pertanyaan)

5. Saran terhadap peningkatan kualitas pelatihan (1 pertanyaan)

Sementara kuesioner yang dibagikan kepada para atasan alumni dan teman kerja alumni hampir samadengan kuesioner di atas, namun dengan sedikit modifikasi disesuaikan dengan target respondennya. Kuesioner yang dibagikan kepada para atasan alumni dan teman kerja alumni ini dimaksudkan untuk mengetahui apakah ada perbedaandalam penilaianyang diberikan oleh alumni dan penilaian yang diberikan oleh pihak lain (atasan dan rekan kerja).

Jenis data yang digunakan adalah datainterval dengan menggunakan metode successive interval dengan menggunakan skala pengukuranLikert sebagaimana yang juga digunakan dalam penelitian Mujiyati (2016). Pernyataan diberikan 
berjenjang dengan 4 (empat) kategorirespons yaitu: 1=kurang, 2=cukup, 3=baik, dan 4=sangat baik.

Kuesioner dibagikan kepada seluruh responden dengan dua cara, yaitu secara langsung dan melalui email. Untuk instansi-instansi yang berada di dalam Kota Batam, Tanjung Pinang dan Tanjung Balai Karimun, responden didatangi di instansi masing-masing sehingga pengisisan kuesioner, observasi dan tanya jawab dapat dilakukan secara langsung. Adapun untuk lokasi-lokasi yang berada di luar Kota Batam, Tanjung Pinang dan Tanjung Balai Karimun, kuesioner dikirimkan melalui email dan tanya jawab (jika diperlukan) dilakukan melalui telepon.

Teknik analisis data yang digunakan dalam penelitian ini adalah analisis model interaktif dari Miles dan Huberman (1992) yang terdiri dari tiga komponen analisis yaitu: reduksi data, penyajian data dan penarikan kesimpulan. Metode analisis statistik deskriptif dan statistik analitik (regresi linier sederhana) juga digunakan dalam analisa data.

\section{HASIL}

Berdasarkan hasil pengolahan data responden, kajian ini menghasilkan data umum responden yang menunjukkan bahwa mayoritas responden $(75 \%)$ adalah wanita, lebih dari setengah responden $(56,45 \%)$ berusia kurang dari 35 tahun, lebih dari 90\% responden berpendidikan antara Diploma 1 (D1) dan Strata 1 (Sarjana), sebagian besar responden $(64,15 \%)$ memiliki masa kerja 5 - 10 tahun, responden dengan status perawat sebanyak 91,94\%, sebagian besar responden bekerja di rumah sakit $(48,44 \%)$ dan puskesmas $(37,50 \%)$. Gambar 1 adalah persentase peningkatan kemampuan alumni Pelatihan Perawatan Luka Tingkat Dasar yang diselenggarakan di Bapelkes Batam tahun 2011-2013 yang menunjukkan adanya peningkatan kemampuan alumni yang sangat signifikan. Peningkatan kemampuan tersebut lebih detil digambarkan pada Gambar 2 dan Gambar 3 yang merinci persentase peningkatan kemampuan alumni berdasarkan seluruh variable yang diujikan dari tiga kelompok responden.Grafik itu juga menunjukkan adanya sebagian kecil dari alumni pelatihan yang kompetensinya tidak meningkat, dan bahkan menurun (yang ini berdasarkan penilaian dari rekan kerja alumni).

Adapun alasan responden mengikuti pelatihan ini, dimana mayoritas responden (76\%) menyatakan bahwa alasan mereka mengikuti pelatihan adalah untuk meningkatkan kualitas SDM, sisanya beralasan karena adanya tuntutan kebutuhan institusi $(16 \%)$, dan karena alasan untuk memenuhi undangan (8\%). 
Tabel 1. Data Alumni Pelatihan Perawatan Luka Tingkat Dasar di Bapelkes Batam Tahun 2011-2013.

\begin{tabular}{|c|c|c|c|c|c|}
\hline Kategori & f & $(\%)$ & Kategori & f & $(\%)$ \\
\hline \multicolumn{2}{|l|}{ Jenis Kelamin } & \multicolumn{4}{|c|}{ Masa Kerja } \\
\hline Laki-laki & 16 & 25.00 & $<5$ & 6 & 11.32 \\
\hline Perempuan & 48 & 75.00 & $5-10$ & 34 & 64.15 \\
\hline \multirow[t]{2}{*}{ Total } & 64 & 100.00 & $>10$ & 13 & 24.53 \\
\hline & & & Total & 53 & 100.00 \\
\hline \multicolumn{6}{|l|}{ Kelompok } \\
\hline \multicolumn{6}{|l|}{ Umur } \\
\hline$<35$ & 35 & 56.45 & Jabatan & & \\
\hline $35-40$ & 20 & 32.26 & Perawat & 57 & 91.94 \\
\hline$>40$ & 7 & 11.29 & Non Perawat & 5 & 8.06 \\
\hline Total & 62 & 100.00 & Total & 62 & 100.00 \\
\hline Pendidikan & & & Instansi & & \\
\hline SLTA & 3 & 4.69 & Rumah Sakit & 31 & 48.44 \\
\hline $\mathrm{D} 1 / \mathrm{D} 2 / \mathrm{D} 3$ & 31 & 48.44 & Puskesmas & 24 & 37.50 \\
\hline $\mathrm{D} 4 / \mathrm{S} 1$ & 28 & 43.75 & Lainnya & 9 & 14.06 \\
\hline $\mathrm{S} 2 / \mathrm{S} 3$ & 2 & 3.13 & Total & 64 & 100.00 \\
\hline Total & 64 & 100.00 & & & \\
\hline
\end{tabular}

Adapun data mengenai faktor-faktor yang menghambat alumni pelatihan dalam melakukan implementasi hasil pelatihan pada unit instansinya menunjukkan bahwa mayoritas responden $(73,44 \%)$ menyatakan bahwa faktor utama yang menghambat implemenetasi hasil pelatihan adalah karena kurangnya dukungan sarana dan prasarana pada unit instansinya.
Secara garis besar, hampir seluruh responden menyatakan apresiasinya atas kepuasan mereka terhadap keberhasilan pelaksanaan pelatihan, walaupun ada sebagian responden yang mengeluhkan adanya ketidaksesuaian dengan kebutuhan instansi (7,94\%) dan kurangnya arahan rencana tindak lanjut $(3,23 \%)$.

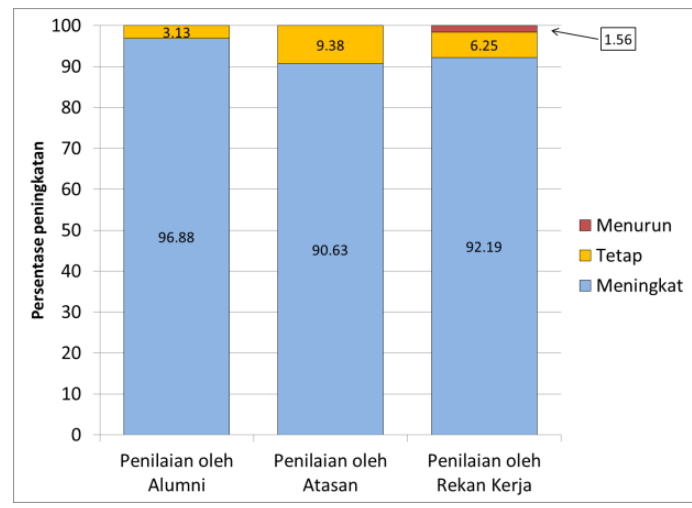

Gambar 1.Persentase Peningkatan Kemampuan Alumni Pelatihan Perawatan Luka Tingkat Dasar di Bapelkes Batam Tahun 2011-2013. 


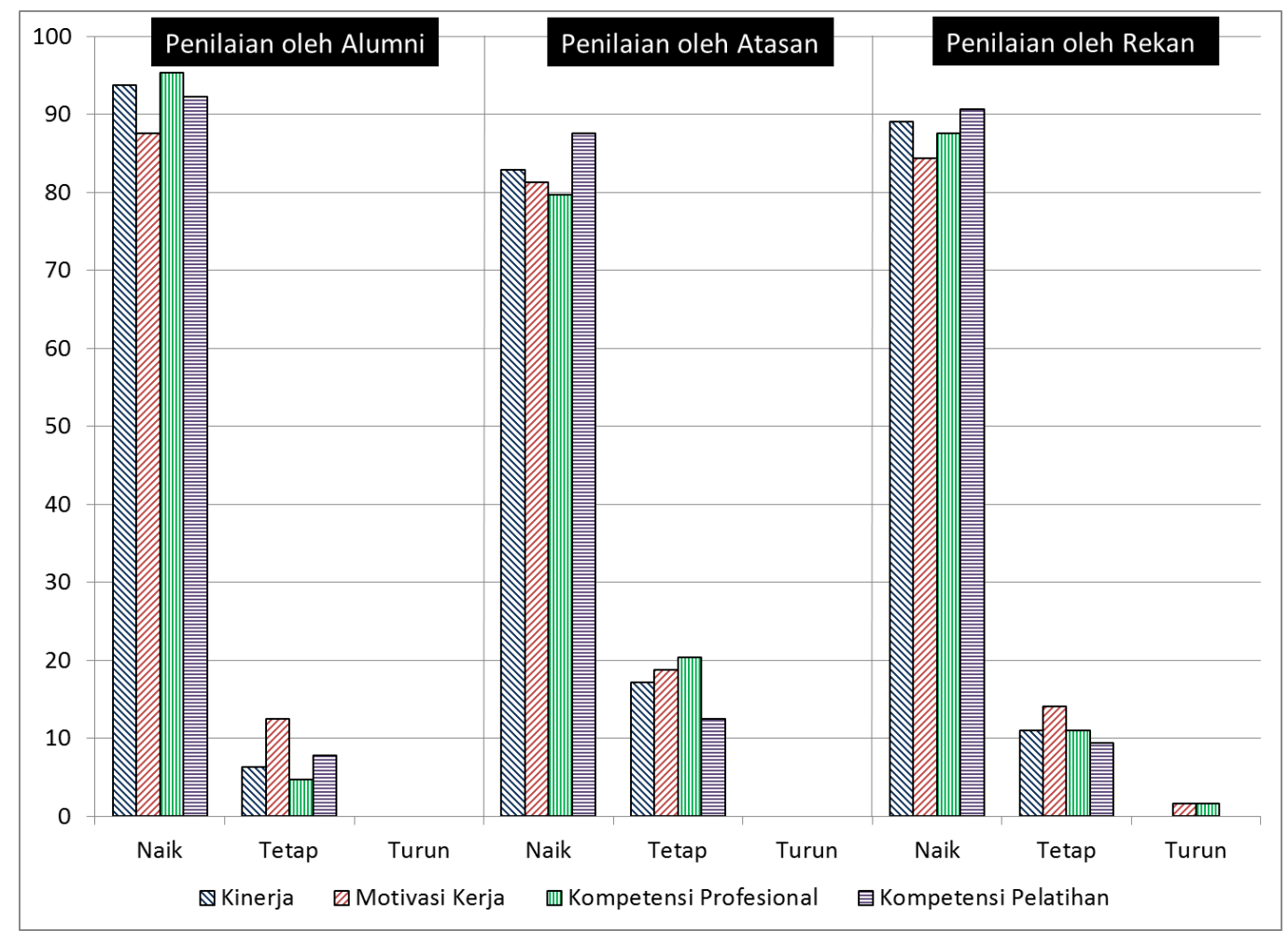

Gambar 2.Persentase Peningkatan Kompetensi Alumni Pelatihan Perawatan Luka Tingkat Dasar di Bapelkes Batam Tahun 2011-2013 Berdasarkan Kelompok Variabel dan Berdasarkan Kelompok Responden.

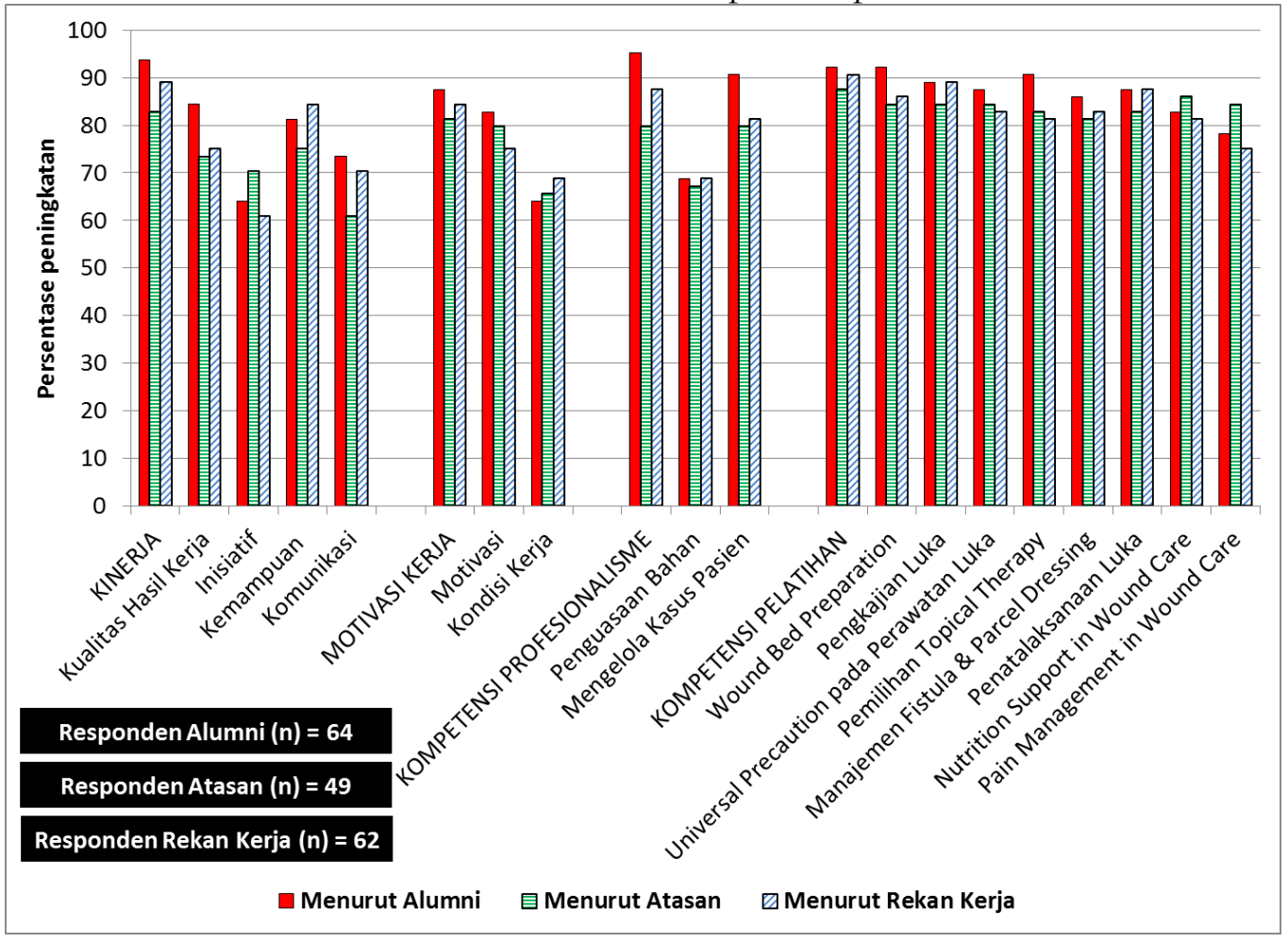

Gambar 3. Persentase Peningkatan KemampuanAlumni Pelatihan Perawatan Luka Tingkat Dasar di Bapelkes Batam Tahun 2011-2013 Berdasarkan Seluruh Variabel Penelitian. 
Untuk mengetahui ada tidaknya bias dalam penilaian yang diberikan oleh alumi pelatihan, atasan alumni dan rekan kerja alumni, sekaligus untuk menguji apakah penilaian yang diberikan oleh ketiga kelompok responden itu memiliki kesamaan (saling mendukung), maka Gambar 4 menyajikan data tersebut. Data ini memberikan petunjuk kepada kita tentang kelompok responden mana yang lebih menunjukkan tingkat kesamaan dalam penilaian.Dari sini dapat dilihat bahwa bahwa penilaian yang diberikan oleh alumni pelatihan dan atasan alumni memiliki hubungan yang sangat kuat dengan koefisien korelasi $\left(\mathrm{R}^{2}\right)$ 0,804 .

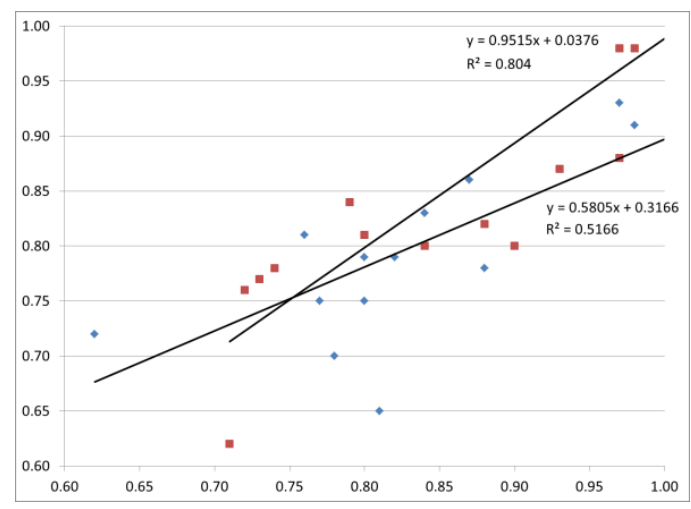

Gambar 4. Grafik Korelasi Penilaian Peningkatan Kompetensi Alumni Pelatihan Antara Penilaian yang Diberikan oleh Alumni Pelatihan dan Atasan Alumni (Merah), serta Penilaian yang Diberikan oleh Alumni Pelatihan dan Rekan Kerja Alumni (Biru).

\section{PEMBAHASAN}

\section{Efektifitas Pelatihan}

Tingkat efektifitas pelaksanaan Pelatihan Perawatan Luka Tingkat Dasar yang dilaksanakan di Bapelkes Batam antara tahun 2011-2013dapat disimpulkan dari data-data responden yang disajikan dalam Gambar 1.Data ini menunjukkan tingkat efektifitas yang tinggi dari pelaksanaan pelatihan, karena pelatihan ini telah mampu meningkatkan kemampuan alumni dengan sangat signifikan (di atas 90\% berdasarkan pendapat seluruh kelompok responden), sebaliknya kemampuan alumni yang tidak meningkat (tetap) hanya berada paling tinggi di bawah angka 9,38\% menurut kelompok responden atasan alumni, dan hanya 3,13\% menurut penilaian alumni pelatihan itu sendiri. Keberhasilan peningkatan kemampuan perawat dalam penanganan luka melalui kegiatan pelatihan juga dilaporkan di antaranya oleh Ahsan, dkk (2013) yakni terdapat perbedaan yang signifikan infeksi nosokomial pada pasien post SC di RS antara sebelum dan sesudah pelatihan berbasis knowledge management.dan Widiyanto, dkk (2013). Hasil penelitian menyimpulkan bahwa terdapat perbedaan antara kelompok yang diberikan pelatihan dan tidak diberi pelatihan.

Gambar 1 juga menunjukkan sebuah fakta dimana kelompok responden rekan kerja 
alumni menilai adanya penurunan kemampuan alumni sebesar $1,5 \%$, sementara penurunan itu tidak terjadi pada penilaian yang diberikan oleh alumni itu sendiri maupun atasan alumni.Variabel yang mengalami penurunan tersebut menurut rekan kerja alumni terjadi pada unsur motivasi kerja dan unsur kompetensi profesional sebagaimana dapat dilihat pada Gambar 2. Adanya alumni pelatihan yang kemampuannya tidak meningkat atau bahkan menurun setelah pelatihan bisa disebabkan oleh banyak aspek, sebagaimana juga terjadi pada studi yang dilakukan oleh Wisastra dan Sagala (2016), bahwa variable pelatihan memiliki pengaruh signifikan terhadap kompetensi karyawan secara simultan dan Turere (2013), didapatkan bahwa pendidikan dan pelatihan dapat mempengaruhi peningkatan kinerja karyawan.

Dalam pelatihan ini, adanya sebagian kecil dari responden yang mengalami penurunan unsur motivasi kerja dan unsur kompetensi profesional (menurut pendapat rekan kerja alumni) mungkin bisa dijelaskan oleh data pada Gambar 4 mengenai alasan mengapa mereka mengkuti pelatihan. Dari Gambar tersebut diketahui ada 8\% responden yang mengikuti pelatihan ini hanya karena untuk memenuhi undangan semata, bukan untuk meningkatkan kualitas SDM, maupun untuk memenuhi kebutuhan instansi. Hal ini tentu akan berimplikasi pada motivasi dan kekurangseriusan peserta dalam mengikuti rangkaian pelatihan. Temuan ini menjadi penting untuk dapat disikapi oleh penyelenggara pelatihan pada kegiatan-kegiatan pelatihan selanjutnya.

Penyebab turunnya motivasi kerja dan kompetensi profesional dari sebagian kecil alumni ini mungkin juga disebabkan oleh kurangnya dukungan sarana dan prasarana yang memadai di instansinya, sehingga hal ini menjadi penghambat para alumni dalam mengimplementasikan teknik-teknik perawatan luka modern yang diajarkan saat pelatihan. Hal itu terindikasikan dari grafik pada Gambar 5 dimana sebagian besar responden $(73,44 \%)$ menyatakan bahwa sarana dan prasarana merupakan faktor penghambat utama dalam implementasi hasil pelatihan.

Kesimpulan di atas pun sejalan dengan persepsi responden terhadap penyelenggaraan pelatihan, dimana 7,94\% responden menjawab bahwa tujuan pelatihan tidak sesuai dengan kebutuhan dan 3,23\% responden menjawab tidak adanya arahan tindak lanjut hasil pelatihan. Kedua hal ini pun bisa saja menurunkan motivasi kerja dan kompetensi profesionalisme dari sebagian kecil alumni pelatihan tersebut.Namun demikian, kesimpulan ini perlu didukung oleh penelitian lebih lanjut.Selebihnya, seluruh responden $(100 \%)$ menyatakan bahwa kegiatan pelatihan telah memenuhi harapan mereka dan kegiatan pelatihan telah memberikan wawasan baru pada mereka. 
Berdasarkan Gambar 1 dan 2, kedua gambar tersebut memperlihatkan bahwa secara umum nilai yang diberikan oleh alumni pelatihan memiliki polakecenderunganyang lebih tinggi daripada nilai yang diberikan oleh atasan alumni dan rekan kerja alumni. Kecenderungan tersebut lebih rinci per variabel dapat terlihat pada Gambar 3, dimana hampir seluruh variabel penilaian yang diberikan oleh alumni pelatihan (red bar) lebih tinggi daripada penilaian yang diberikan oleh atasan alumni (borizontalgreen) dan rekan kerja alumni (diagonal blue).Hal ini boleh dikatakan wajar, karena dalam hal ini responden menilai dirinya sendiri, sehingga subyektifitas mungkin saja terjadi, sebagaimana dijelaskan oleh studi-studi lain yang melibatkan responden yang menilai diri sendiri (self assessment) sebagaimana dijelaskan oleh Sururi, dkk., (2016) mendapatkan hasil bahwa penilaian kinerja organisasi seluruhnya dapat dilihat dari sekolah dan kepala sekolah membangun profesionalitas dan Chasanah, dkk., (2015) dengan hasil penelitian dengan rating scale, tidak terdapat perbedaan yang signifikan antara penilaian dari berbagai sumber (atasan dan rekan kerja) dengan penilai diri sendiri. Untuk itulah maka diperlukan pihak lain sebagai responden eksternal yang dapat menjadi pembanding dan pengkoreksi terhadap subyektifitas tersebut. Hal ini akan dijelaskan tersendiri melalui analisa regresi pada Sub Bab Korelasi Antar Responden.
Dari Gambar 3, dapat disimpulkan bahwa penilaian responden pada variable-variable pada unsur Kompetensi Pelatihan lebih konstan di atas angka 75, hal ini dapat memberikan indikasi bahwa penilaian pada aspek psikomotorik alumni lebih baik dan stabil. Sementara pada unsur Kinerja, Motivasi Kerja, dan Kompetensi Profesional, nilainya lebih fluktuatif, yang menunjukkan adanya disparitas kemampuan alumni. Fluktuasi nilai terendah terjadi pada variable insiatif, komunikasi, dan kondisi kerja (aspek afektif), serta variabel penguasaan bahan (aspek kognitif).

Terkait dengan penyelenggaraan pelatihan, secara umum responden menilai bahwa penyelenggaraan pelatihan sangat baik.Di antara parameter yang masih memerlukan penguatan adalah muatan modul / bahan ajar dan penggunaan metode belajar dimana skor nilainya masih di bawah 3,15 dengan bobot di bawah $80 \%$.

\section{Korelasi Antar Responden}

Grafik korelasi yang dihasilkan dari analisa regresi sederhana yang ditunjukkan pada Gambar 4 menunjukkan adanya hubungan yang kuat pada kesamaan penilaian yang diberikanoleh kelompok-kelompok responden.Untuk korelasi penilaian yang diberikan alumni pelatihan dan atasan alumni menghasilkan nilai koefisien korelasi $\left(R^{2}\right)$ 0,804 dengan persamaan regresi $y=0,9515 x+0,0376$ yang membuktikan pola kesamaan penilaian 
yang sangat tinggi (bighy significant). Sedangkan hubungan antara penilaian yang diberikan oleh alumni pelatihan dan rekan kerja alumni menghasilkan nilai $\mathrm{R}^{2}$ sebesar 0,516 dengan persamaan regresi $y=0,5805 x+0,3166$, yang mengindikasikan hubungan yang kuat (significant), menunjukkan penilaian responden dianggap obyektif, sebagaimana juga terjadi pada kajian yang dilakukan oleh Susilo (2016), dengan hasilnya bahwa tidak ada perbedaan penilai kompetensi oleh alumni, atasan dan sejawat sehingga dianggap objektif.

\section{KESIMPULAN}

Studi ini bertujuan untuk mengetahui efektifitas penyelenggaraan Pelatihan Perawatan Luka Tingkat Dasar di Bapelkes Batam Tahun 2011-2013 dalam meningkatkan kemampuan peserta pelatihan. Hal-hal pokok yang dihasilkan dari studi ini adalah:

Pelatihan telah berhasil sangat efektif dalam meningkatkan kemampuan alumni pada seluruh variable yang diujikan dengan rata-rata persentase peningkatan sebesar 96,88\% (menurut alumni), 90,63\% (menurut atasan), dan 92,19\% (menurut rekan kerja).

Terdapat hubungan kesamaan antara penilaian yang diberikan oleh antar kelompok responden dengan koefisien korelasi $\left(\mathbf{R}^{2}\right)$ 0,804 untuk korelasi antara penilaian alumni pelatihan dan atasan alumni serta 0,516 untuk korelasi antara penilaian alumni pelatihan dan rekan kerja alumni.

Terdapat sebagian kecil (1,56\%) alumni pelatihan (menurut penilaian rekan kerja alumni) yang mengalami penurunan motivasi kerja dan kompetensi profesional yang diduga disebabkan oleh motivasi awal (alasan) peserta mengikuti pelatihan dan oleh kurangnya dukungan sarana prasarana di instansinya.

\section{SARAN}

Penelitian ini dapat dilanjutkan dengan kesinambungan pelatihan dimasa yang akan datang serta evaluasi yang dilakukan pasca pelatihan sesuai jadwal yang sudah ditentukan

\section{UCAPAN TERIMAKASIH}

Ucapan terima kasih disampaikan kepada Kepala Balai Pelatihan Kesehatan Batam Kemenkes RI beserta seluruh staf dan widyaiswara yang telah membantu memfasilitasi pelaksanaan penelitian ini.

\section{REFERENSI}

Ahsan, Nursalam, dan Damayanti, N.A., 2012. Penurunan Insiden Infeksi Nosokomial Pasien Pasca Sectio Caesarea di Rumah Sakit melalui Pelatihan Asuhan Keperawatan Berbasis Knowledge Management.Jumal Ners, 8(2), 202-210.

Atmodiwirio, S., 2000. Manajemen Pendidikan Indonesia, Penerbit Ardadizya Jaya, 358 p., Jakarta.

Bloom, B. S., Englehart, M. D., Furst, E. J., Hill, W. H., and Krathwohl, D. R., 1956. The Taxonomy of educational objectives, handbook I: The Cognitive domain. New York: David McKay Co., Inc. 
Busyra, N., 2011. Survei Kepuasan Peserta Diklat terhadap Kualitas Pelayanan Instruktur Pelaksanaan Diklat Pengawas dan Kepala Madrasah Kementerian Agama RI di UHAMKA, Prosiding Penelitian Bidang Ilmu Sosial dan Humaniora, 202-269.

Chasanah, T.D., Effendi, U., dan Silalahi, R.L.R., 2015. Penilaian Kinerja Karyawan Bagian Personalia Berdasarkan Kompetensi dengan Metode 360 Derajat (Studi Kasus di PG Kebon Agung - Malang). Jurnal Industria, 4(1), 31-40.

Dahro, A.M., Komala, K., Mudjianto, T.T., Suwardi, S.S. dan Mahdar, D., 2012. Status Gizi Mikro (Tembaga Seng dan Kromium) Pengetahuan Gizi dan Keadaan Gizi Lebih pada Pria Pekerja, Penelitian Giæi dan Makanan, 139-150.

Fata, U.H., Rahmawati, A., Wulandari, N., Fanani, Z. dan Prayogi, B., 2016. Pusat Perawatan Luka Patria Care Blitar Unit Pelayanan Perawatan Luka, Konseling, Produk Salep Luka dan Pelatihan Perawatan Luka, Jurnal Dedikasi, 13(1), 9-15.

Gibson, J.L., Ivancevich, J.M., and Donelly, J.H., (Alih Bahasa: Djoerban Wahid) 1997. Organisasi dan Manajemen: Perilaku, Struktur, dan Proses, 377 p., Penerbit Erlangga, Jakarta.

Gomes, F.C., 2005. Manajemen Sumber Daya Manusia, 260 p., Penerbit ANDI, Yogyakarta.

Halim, A.S., Khoo, T.L, Mat Saad, A.Z., 2012. Wound bed preparation from a clinical perspective. Indian Journal of Plastic Surgery, 45(2), 193-202.

Handayani, L.T., 2016. Studi Meta Analisis Perawatan Luka Kaki Diabetes dengan Modern Dressing, The Indonesian Journal of Health Science, 6(2), 149-159.

Miles, B.M. dan Huberman, A.M., (Alih Bahasa: Tjetjep Rohendi Rohidi) 1992. Analisis Data Kualitatif: Bukn Sumber tentang Metode-Metode Baru, 491 p., Penerbit Universitas Indonesia Press, Jakarta.
Mujiyati, Wahab, Z., 2016. Analisis Pengaruh Motivasi, Pengetahuan, dan Sikap Konsumen terhadap Pengambilan Keputusan dalam Penggunaan Orthodonsi pada Siswa Sekolah Menengah Atas Negeri di Kota Palembang, Jurnal Kedokteran dan Kesehatan, 3(1), 373-376.

Nontji, W., Hariati, S. dan Arafat, R., 2015. Teknik Perawatan Luka Modern dan Konvensional terhadap Kadar Interleukin 1 dan Interleukein 6 pada Pasien Luka Diabetik, Jurnal Ners, 10(1), 133-137.

Notoatmodjo, S., 2009. Pengembangan Sumber Daya Manusia, Cetakan Keempat, 180 p., Penerbit Rineka Cipta, Jakarta.

Prahastuti, S., 2011. Konsumsi Fruktosa Berlebihan dapat Berdampak Buruk bagi Kesehatan Manusia, Jurnal Kedokteran Maranatha, 10(2), 173-189.

Robbins, S.P., 1996. Perilaku Organisasi Konsep Kontroversi Aplikasi, 349 p., Penerbit Prenhallindo, Jakarta.

Rostini, R., Intang, A. dan Darwis, D., 2013. Pengaruh Penggunaan Larutan NaCL $0,9 \%$ terhadap Lama Hari Rawat pada Pasien Vulnus Laceratum di Rumah Sakit Umum Daerah H. Andi Sulthan Daeng Radja Kabupaten Bulukumba, Jurnal Ilmiah Kesehatan Diagnosis, 2(4), 1-6.

Sururi, Saud, U.S., dan Suryana, A., 2016. Studi Efektifitas Penilaian Kinerja Kepala SMP Negeri. Jurnal Administrasi Pendidikan, 23(2), 161-172.

Susilo, B., 2016.Analisis Pengaruh Desain Program Diklat Bendahara Pengeluaran (DTSS) terhadap Kompetensi Bendahara Pengeluaran.Info ARTHA, 2(5), 37-46.

Turere, V.N., 2013. Pengaruh Pendidikan dan Pelatihan terhadap Peningkatan Kinerja Karyawan pada Balai Pelatihan Teknis Pertanian Kalasey.Jurnal EMBA, 1(3), 10-19.

Widiyanto, P., Hariyati, R.T.S., dan Handayani, H., 2013.Pengaruh Pelatihan Supervisi Terhadap 
Care: Jurnal Ilmiah Ilmu Kesehatan Vol .7, No.3, 2019, hal 84-96

Penerapan Supervisi Klinik Kepala Ruang dan Peningkatan Kualitas Tindakan Perawatan Luka di RS PKU Muhammadiyah Temanggung.Prosiding Konferensi Nasional PPNI Jawa Tengah, 44-51.
Wisastra, P.I.Y., dan Sagala, E.J., 2016. Pengaruh Pelatihan terhadap Kompetensi Karyawan PT. LEN INdustri (Persero) Bandung.Matrik: Jurnal Manajemen, Strategi Bisnis dan Kewirausabaan, 10(2), 98-109. 